Research Article

\title{
Gadgets and Messenger Applications as an Instrument for Secondary School Administration
}

\author{
Vadym Luniachek $\mathbb{D}^{1}$ and Tetyana Varenko $\mathbb{i D}^{2}$ \\ ${ }^{1}$ Creative Pedagogy and Intellectual Property Department, Ukrainian Engineering Pedagogics Academy, Kharkiv 61003, Ukraine \\ ${ }^{2}$ Department for Cooperation with International Agencies and Financial Institutions, Kharkiv City Council, \\ Kharkiv 61200, Ukraine \\ Correspondence should be addressed to Tetyana Varenko; t.k.varenko@gmail.com
}

Received 13 February 2021; Accepted 6 May 2021; Published 10 May 2021

Academic Editor: Harco Leslie Hendric Spits Warnars

Copyright (c) 2021 Vadym Luniachek and Tetyana Varenko. This is an open access article distributed under the Creative Commons Attribution License, which permits unrestricted use, distribution, and reproduction in any medium, provided the original work is properly cited.

\begin{abstract}
This research is intended to study the influence that gadgets and messenger applications have on the management process in institutions of general secondary education (IGSE) in Ukraine. The relevance thereof is conditioned by the fact that this subject matter has never been previously in the focus of any specific research in either Ukraine or the world. It relies on the data collected through an online questionnaire distributed among the IGSE administrators of Ukraine. The findings reveal that the use of gadgets and messenger applications in IGSEs is becoming new normal in the management activity of the IGSE administrators while raising a number of ethical questions related to violation of the subordinates' rights to privacy and personal time and space.
\end{abstract}

\section{Introduction}

Computation intelligence technologies are being extensively integrated into all aspects of people's lives producing new and ever more advanced products, such as computers, smart devices, mobile phones, and all kinds of gadgets equipped to serve all kinds of purposes. Accelerated development of IT technologies in the late XX-early XXI centuries has been pushing the population of the planet to mass use of such devices and gadgets. Their appearance on the market has fundamentally changed the approaches to solving a number of tasks, inter alia, in information sharing and communication. The management processes, in particular in education, are no exception in this context. The use of these devices significantly impacts and changes performance of management functions in the education system, especially those of organization, control, communication, etc. At the same time, as yet, there has been no systematic research conducted in the education system of Ukraine to study the impact of gadgets and messenger applications on management processes, or the view of representatives of certain professional groups as to the use of gadgets in communication processes, etc. Therefore, this study is one of the first attempts undertaken in this direction.

1.1. Analysis of Research and Publications. In preparation for this research, we have analyzed the open-access materials available today on the use of modern gadgets in education management. This enabled us to conclude that the majority of works in this subject are related to the support of the academic process in institutions of education. As for the use of gadgets in education management, this is significantly underresearched, with only sparse publications on the matter. For instance, there is a paper by Golenko on the use of gadgets in the education process as a tool of education quality management. Based on the results of an online poll, the author made a conclusion about the active penetration of gadgets into the sphere of education and their transformation into an instrument of education quality management emphasizing that the youth, being the most creative part of the society that positively accepts change, is today's major consumer of educational services [1]. At the same time, this study focuses on the issues of the education process 
organization rather than on pure management activity of administrators of educational institutions, and the emphasis is on higher education. Similar issues are addressed by Golovyashkina in her studies of use of gadgets in the education process of a university at different stages. The author explicitly stresses the positive impact thereof on the education quality [2].

It is worth mentioning that a vast majority of the national sources study the influence of gadgets on students' health and the problems related to their use in the educational process. Most of such works are publicistic rather than scientific in nature.

The analysis conducted enables us to state the fact that the research presented below is the first such attempt not only in Ukraine, but also in the post-Soviet countries, an attempt to analyze the impact of the modern gadgets on management processes in the general secondary education system.

The same situation is observed in the international scientific community. While there are numerous and multifaceted studies of use of gadgets in the classroom, its effect on the students' academic performance and health, there seems too to be no significant research of their use by secondary school administrators in their management activity.

Occasionally, there would emerge studies under the title of "School Management in 21st Century Using ICT: Challenges and the Way Forward," for example, which suggests that the subject matter would cover the ICT in the management activity of school administrators. However, upon thorough examination, it becomes clear that it primarily deals with the ability of school leaders to select and implement "the tools teachers will use to engage students and improve learning" [3].

Similarly, Serhan's research on school principals' attitudes towards the use of technology reveals a positive attitude of school principles to ICT use in teaching viewing it as "an enhancement to the classroom" ([4], p. 46).

The doctoral thesis in educational management "The management challenges of using information communication technology for administration at secondary schools in Kirinyaga county, Kenya" by Muriithi Stephen Njoka, with reference to Krishnaveni and Meenakumari ([5], p. 282), indicates general administration among the main areas for ICT use in educational management, the others on the list being payroll and financial accounting, student data administration, inventory management, personnel records maintenance, etc. ([6], p. 10). Although it is worth mentioning that Krishnaveni and Meenakumari [5] deal with the higher education environment, similar to the study by Kupoluyi [7], the MS degree paper by Said Gedwar titled "Use of ICT for Administration and Management: Case Study, EMU" provides an interesting insight into the use of ICT in the daily work of university administrators [8].

With reference to Maki (2008), Njoka maintains that ICTs among other things enable education administrators "to communicate data, that is exchange messages and data between school staff and other schools or organizations" ([6], p. 9).
Hoque et al. in their research conducted on ICT use by teachers and principals in Malaysia point out that "principals or headmasters have to understand that the function of ICT in schools does not serve primarily to promote computer literacy" and mention "daily administrative functions of the school," although without specifying what the latter include [9].

A study conducted at education schools of Nigerian universities in 2018 investigated the availability and use of ICT gadgets to conclude that these should be available and used in teaching and learning [10]. Another Nigerian study indicates that ICT integration in secondary schools significantly underperforms due to the lack of the relevant funding, facilities, and ICT literacy of the staff, which negatively affects the quality of the educational process provided to students [11].

Studies emphatically confirm that ICT in secondary school are particularly important not only for teaching and learning, but also for record keeping and inter- and intracommunication [12].

The job performance of school administrators can significantly improve if they effectively use such ICT as email, database management systems, Internet, and word processing tools in exercise of their functional duties [13].

Another study of the use of modern electronic gadgets in the university setting conducted at the Russian State Social University in 2018 confirmed the important role that modern gadgets play in the educational process in terms of students' communication and learning [14].

Researchers from Kenya looked into the secondary school principals' attitude to computer use in school administration to reveal that ICT use by Kenyan school principals is almost nonexistent despite the growing popularity of mobile phones and that an awareness-raising campaign is long overdue among the school administrators to improve the situation [15].

A survey conducted among college principals also confirms that it is becoming more and more essential for the educational administrators to use ICT technologies for "educational assessment, support and management, ethical, social and legal issues for supporting and enriching instructional environment" [16].

The findings of the study by Antonio and Lorenzo indicate that the scope of training received by the school administrators, the family members' influence, own personal beliefs and attitudes to ICT have a significant impact on the decisions of the school administrators to adopt and use ICT in the performance of their managerial functions [17].

In 2019, there was a Doctor of Education dissertation defended in the field of education leadership that investigated the correlation between school administrators' technology leadership preparation and technology integration in the schools [18]. It concludes that "school leaders must become the primary visionaries and promoters of educational technology" in the students' learning [Ibid, p. 100].

Similar findings were received in Sweden where a survey revealed school principals' willingness to participate in digitalization trainings and satisfaction with their content, which enabled them to learn and better understand the 
digitalization process and how it can be applied in their schools [19].

The secondary school administrators' opinions on the use of mobile technologies for educational purposes have been screened in a study conducted by İa et al. whose findings indicate positive changes in the teaching and learning activities that employ mobile technologies [20].

Internet tools can be an effective aid in school management, too. Studies show that school principals favour using such Internet tools as "search engines, eail services, online storage systems, social media, Google docs, e-records management tools, online security apps, open office and e-timetable apps" in their management of the school [21].

An interesting study is one analysing the use of social media in school management in Ukraine and USA. It reveals the biased attitude towards the social media among the school administration in Ukraine who majorly regard them as entertainment and therefore a priori refute the idea of using those for educational purposes, while their American colleagues perceive them as valuable didactic resource that can help successfully arrange the educational process [22].

As for the students' expectations from and perceptions of school administration quality, recent studies reveal a significant gap between those and the actual state of affairs as the use of ICT tools for communication is highly expected but not as commonly practised [23].

In the times of the COVID-19 pandemic, the issue of educational administrators' competence in use of ICT, gadgets and messenger applications, is gaining more and more momentum and relevance. Of course, it primarily applies to the distance learning organization, which can only be effectively and efficiently integrated in an education institution with a digitally savvy administrator. One of the most recent studies to confirm this idea is that by Asio and Bayucca [24].

In addition to that, it is important to point out that the government support must be an integral part of any process if we want it to make a visible change and lasting tangible results on the national scale and in the long run. Education is not an exception to this rule. Therefore, a well-envisioned and consistent policy for ICT integration in the educational administration is required [25].

It is evident that the use of gadgets and messenger applications in the secondary school administrators' activity as managers is a blind spot in the scientific research and has never been a subject matter of specific studies. And while there is no doubt that ICT and gadgets in teaching and learning activities are important, this issue has been receiving the spotlight in the scientific and educational communities for years now, of which there are numerous indications in articles, conference proceedings, and other publications, including most of the cited above. However, teaching and learning are not the only aspects of effective school operation. How well organized and efficient is the communication between the administration and the staff of the educational institution is no less important and deserves a dedicated study as this communication is key to ensuring smooth running of any school as well-balanced mechanism.
1.2. Purpose Statement. This research is intended to study the influence that gadgets and messenger applications have on the management process in institutions of general secondary education (IGSE) in Ukraine.

\section{Materials and Methods}

By the information from the Ministry of Education and Science of Ukraine in 2020, there were 15,200 institutions of general secondary education in the country [26]. The survey conducted within this research covered 1,791 IGSE administration representatives, particularly, 1,186 IGSE directors (principals) (66.2\%), and 605 deputy directors (principals) (33.8\%). The polling was undertaken using the Google Form instrument in the form of a questionnaire available to the participants by link. Since the survey no longer accepts responses to the questionnaire, how the original form of the questionnaire appeared to the respondents is available at http://www.t.ly/Vsw1. All the answers collected for this questionnaire within this survey are available at http://www.t.ly/g9H3.

The selection was random within the homogeneous general population of IGSE administrators of Ukraine who participated in the survey on a voluntary basis. The polling took place in December 2020 and was anonymous for the participants to ensure more truthful answers. The use of the results obtained hereby is only provided for in a generalized form. The survey was conducted by the Department of Creative Pedagogy and Intellectual Property of the Ukrainian Engineering Pedagogics Academy according to the scientific research plan of the Department.

2.1. Findings and Discussion. The surveyed consisted of 1,448 women (80.8\%) and 343 men (19.2\%). This shows that the men-women ratio in the IGSE management system in Ukraine is $1: 4$.

There were 1,787 respondents who indicated their age. The distribution by age is presented in Table 1 .

The indicators presented indicate an ageing tendency among the IGSE administrators as the majority (51.6\%) are 50 years old and older. This is particularly evident in the analysis of individual oblasts; for example, Lvivska oblast in the west of Ukraine has this indicator at the level of $61.8 \%$ (Table 2).

As an example of age groups presentation by one oblast situated in the east of Ukraine, Table 3 provides answers for Kharkivska oblast. The data demonstrate that the age of IGSE administrators is closest to normal.

There were no territorial limitations for participation in the survey. At the same time, IGSE administrators' zeal varied significantly across Ukraine (Table 4).

What is a positive sign is that the majority of oblasts of Ukraine participated in the survey, which enables identifying specific features of different regions: western (Lvivska, Rivnenska, Ivano-Frankivska, and other oblasts), eastern (Luhanska, Kharkivska, and other oblasts), central (Kyivska, Poltavska oblast, and the city of Kyiv), northern (Sumska, Chernihivska, and other oblasts), and southern (Odeska and other oblasts). 
TABLE 1: IGSE administrators by age groups.

\begin{tabular}{lcc}
\hline Age group & Number of responses & $\%$ \\
\hline $20-30$ years old & 40 & 2.2 \\
$30-40$ years old & 198 & 11.1 \\
$40-50$ years old & 627 & 35.1 \\
$50-60$ years old & 643 & 36 \\
$>60$ years old & 279 & 15.6 \\
\hline
\end{tabular}

TABLE 2: IGSE administrators by age groups in Lvivska oblast.

\begin{tabular}{lcc}
\hline Age group & Number of responses & $\%$ \\
\hline $20-30$ years old & 4 & 0.9 \\
$30-40$ years old & 43 & 9.9 \\
$40-50$ years old & 119 & 27.4 \\
$50-60$ years old & 169 & 38.9 \\
$>60$ years old & 99 & 22.9 \\
\hline
\end{tabular}

TABLE 3: IGSE administrators of Kharkivska oblast by age groups.

\begin{tabular}{lcc}
\hline Age group & Number of responses & $\%$ \\
\hline $20-30$ years old & 11 & 3.5 \\
$30-40$ years old & 36 & 11.3 \\
$40-50$ years old & 128 & 40.1 \\
$50-60$ years old & 115 & 36.1 \\
$>60$ years old & 29 & 9.1 \\
\hline
\end{tabular}

TABLE 4: IGSE administrators by oblasts of Ukraine.

\begin{tabular}{lcc}
\hline Oblast & No. of persons & $\%$ \\
\hline Vinnytska oblast & - & - \\
Volynska oblast & - & - \\
Dniprovska oblast & 5 & 0.3 \\
Donetska oblast & 2 & 0.1 \\
Zhytomyrska oblast & 1 & 0.1 \\
Zakarpatska oblast & 5 & 0.3 \\
Zaporizka oblast & 3 & 0.2 \\
Ivano-Frankivska & 23 & 1.3 \\
Kyivska oblast & 49 & 2.7 \\
Kirovohradska oblast & - & - \\
Luhanska oblast & 85 & 4.7 \\
Lvivska oblast & 436 & 24.3 \\
Mykolaivska oblast & - & - \\
Odeska oblast & 86 & 4.8 \\
Poltavska oblast & 76 & 4.2 \\
Rivnenska oblast & 124 & 6.9 \\
Sumska oblast & 89 & 5 \\
Ternopilska oblast & - & - \\
Kharkivska oblast & 319 & 17.8 \\
Khersonska oblast & 1 & 0.1 \\
Khmelnytskyi oblast & - & - \\
Cherkaska oblast & - & - \\
Chernivetska oblast & - & - \\
Chernihivska oblast & 130 & 7.3 \\
Autonomous Republic of Crimea & - & - \\
City of Kyiv & 356 & 19.9 \\
Total & 1791 & 100 \\
\hline
\end{tabular}

The survey results revealed that the majority of IGSE administrators use modern gadgets in their management activity $-1,710$ people (95.5\%), of which 1,106 (61.8\%) use them as a means of information sharing with their subordinates and 889 (49.6\%) - for setting tasks for individual staff members. At the same time, the absolute majority of administrators $(1,580$, or $88.2 \%)$ communicate via groups created for specific topics or issues.

The survey also showed that the vast majority of IGSE administrators $(1,570$, or $87.7 \%)$ prefer Viber. Table 5 presents the choices of messenger applications in more detail. It is worth mentioning though that there are no significant deviations in the answers to this question by oblasts across Ukraine.

The survey results indicate that the use of gadgets in IGSE management in Ukraine has somewhat negative tendencies in the administrators' attitude to respect of personal space of their subordinates during their nonworking hours: 996 respondents (55.6\%) use gadgets for dissemination of administrative information on a roundthe-clock basis, and only $795(44.4 \%)$ do that within the working hours. This tendency is stable today and we believe is likely to increase. It is worth pointing out that this issue should require urgent regulation both at the normative and ethical levels. The situation we are witnessing today considerably affects the personal lives of the staff employed in secondary education and may cause conflicts between family members, professional burnout, and depressive disorders. Moreover, analysis within individual oblasts showed that Dniprovska oblast's indicator of round-the-clock dissemination of administrative information was $100 \%$ and that of Sumska oblast was $-73 \%$. Having received this data, we are now considering further studies in this area to develop propositions as to regulations for the relevant activity in terms of professional activity of particular professional groups.

The question if use of gadgets in the management activity impacts the personal space of the staff and their personal time received only $40.8 \%$ (731 respondents) of positive answers, while every fourth (451) IGSE administrator is of the opposite opinion, and 609 respondents (34\%) could not give a definite answer to the question. At the same time, more categorical in their response were the representatives of larger administrative-territorial units, such as Kharkivska oblast, where the significant influence of gadget use for the work purposes on the staff's personal time and life is acknowledged by as many as $76.8 \%$, or Odeska oblast with the indicator being $59.3 \%$, or Kyivska oblast with $46.1 \%$.

The survey revealed that every third IGSE administrator (564 answers, 31.5\%) was concerned and unhappy when their subordinates ignored their requests to send something via messenger applications; about as many (584) respondents $(32.6 \%)$ claimed to be okay with this attitude; the rest (643 respondents, or 35.9\%) hesitated in their response. The distribution of answers by oblasts did not show any significant deviations, which suggests the situation is similar across the entire country and is not inherent to any particular territory. These answers suggest that there is still no well-established attitude or line of conduct in relation to superior-subordinate communication via messenger applications that is acknowledged and accepted by both sides of this communication. 
TABle 5: Messenger applications used by Ukrainian IGSE administrators in their management activity.

\begin{tabular}{lcc}
\hline Messenger application & No. of persons & $\%$ \\
\hline Viber & 1570 & 87.7 \\
Skype & 12 & 0.7 \\
Facebook Messenger & 119 & 6.6 \\
Telegram & 62 & 3.5 \\
WhatsApp & 28 & 1.6 \\
\hline
\end{tabular}

At the same time, whenever IGSE administrators conduct meetings, the majority of them emphasize to their subordinates that the latter should read instructions and requests received via gadgets: $1,105(61.7 \%)$ do that regularly and $513(28.6 \%)$ occasionally. No such requests would come from IGSE administrators in only 173 responses (9.7\%). However, when it comes to using gadgets and messenger applications to disseminate orders related to the main professional activity, about half of the respondents (811 answers, or $45.3 \%$ ) believe this to be inexpedient, while $19.9 \%$, or 356 , IGSE administrators do this regularly and 624 (34.8\%) from time to time. In general, across Ukraine, this indicator for administrators who emphasize the need to read their instructions and requests sent via gadgets is above average for Kyivska oblast (65.7\%) and Lvivska oblast (65.4\%), which indicates the attitude to gadgets in management is more tech-savvy in the capital and in the most western region of Ukraine.

Most respondents believe that gadgets can significantly improve the management activity. This is the opinion of 1409 survey participants (78.7\%). However, about every fifth IGSE administrator (372 participants, or $20.8 \%$ ) is actually hesitant to answer this question and 10 respondents $(0.6 \%)$ gave a negative answer. Analyzed by oblasts, the data received from different oblasts vary insignificantly. This suggests that there exists positive experience of gadgets use in the management practices in IGSEs across Ukraine, and its effect on quality and convenience of the process is regarded by the majority as positive and welcomed.

IGSE administrators also evaluated by a 10-point scale the degree to which the management processes improved with the use of gadgets and messenger applications therein. The answers to this question were given by 1656 survey participants (Table 6) and illustrate an overall positive trend with the overwhelming majority confirming the noticeably positive effect from the use of gadgets on the management process.

As for IGSEs having a particular system using gadgets and messenger applications in improvement of management processes, 615 administrators of such IGSEs (34.3\%) indicated having such systems, while the majority, 1176 administrators $(65.7 \%)$ admitted to having none.

Those exploiting the benefits of the gadget/messenger application system were also to indicate the main principles thereof, the algorithms of its use, etc. The 382 detailed answers given can be grouped as addressing the following issues:

(i) Handling urgent matters: providing additional information during distance learning; distributing
TABLE 6: IGSE administrators' view on improvement of management quality through use of modern gadgets and messenger applications.

\begin{tabular}{lcccccccccc}
\hline Score & 1 & 2 & 3 & 4 & 5 & 6 & 7 & 8 & 9 & 10 \\
\hline $\begin{array}{l}\text { No. of } \\
\text { persons }\end{array}$ & 1 & 4 & 17 & 34 & 192 & 125 & 308 & 495 & 220 & 260 \\
$\%$ & 0.1 & 0.2 & 1 & 2.1 & 11.6 & 7.5 & 18.6 & 29.9 & 13.3 & 15.7 \\
\hline
\end{tabular}

news from the Ministry of Education and Science of Ukraine and the Ministry of Health of Ukraine; creating topic-related and temporary groups by particular subject matter (a constantly operating group of tutors; an administration group; a group for provision of information on students' attendance of academic classes; a temporary group to prepare for the pedagogical council session, and the like).

(ii) Providing information on materials uploaded to Google Drive, including orders related to the main activity: creating a virtual teaching staff room; providing a space for a depository of relaxation materials; providing a space for communication with the parents' community; providing a space for communication with IGSE graduates; conducting urgent polls; providing photo reports, etc.

These answers clearly illustrate the diversity of uses thatgadgets and messenger applications have in IGSE management as well as in communication and collaboration between various participants of the educational process. The respondents were to evaluate on a 1-to-10 scale how less frequent their face-toface meetings in their IGSEs became thanks to the use of gadgets and messenger applications (Table 7).

In some oblasts of Ukraine, these indicators are more significant. The results for the capital city of Kyiv are presented in Table 8. The results indicate a positive tendency, which enables IGSE administrators to free up a significant share of working hours for other work and activities.

The IGSE administrators also answered the question if the education governing bodies use gadgets to work with them as IGSE administrators. The overwhelming majority answered positively $(84.4 \%)$ and regard this as a positive practice $(94.3 \%)$, which confirms that gadgets in administration routine are an important and effective tool of work and communication.

As for the means of information provision by the education governing bodies, most IGSE administrators (1,326 respondents, $74.3 \%$ ) give preference to it being emailed to them, 20.9\% (372 respondents) prefer messenger applications, and only $4 \%$ (71 respondents) are for traditional means of information transfer and $0.8 \%$ (15 respondents) hesitated.

At the end of the survey, IGSE administrators were to rate the overall impact of modern gadgets on the management quality in institutions of general secondary education on a 1-to-10 scale (where 1 means the impact is insignificant and 10 stands for such impact being significant) (Table 9). The results reveal that the overwhelming majority attribute more-than-average significance to the impact of gadgets on management quality. 
TABLE 7: IGSE administrators' view on cut-down in face-to-face meetings thanks to the use of modern gadgets and messenger applications.

\begin{tabular}{lcccccccccc}
\hline Rating scale & 1 & 2 & 3 & 4 & 5 & 6 & 7 & 8 & 9 & 10 \\
\hline $\begin{array}{l}\text { No. of } \\
\text { persons }\end{array}$ & 149 & 139 & 218 & 174 & 541 & 136 & 138 & 172 & 103 & 28 \\
$\%$ & 7.9 & 7.8 & 12.2 & 9.7 & 30.2 & 7.6 & 7.7 & 9.6 & 5.8 & 1.6 \\
\hline
\end{tabular}

TABLE 8: Kyiv IGSE administrators' view on cut-down in face-toface meetings in favour of those with modern gadgets and messenger applications.

\begin{tabular}{lcccccccccc}
\hline Rating scale & 1 & 2 & 3 & 4 & 5 & 6 & 7 & 8 & 9 & 10 \\
\hline No. of answers & 9 & 11 & 18 & 16 & 95 & 21 & 37 & 77 & 57 & 15 \\
$\%$ & 2.5 & 3.1 & 5.1 & 4.5 & 26.7 & 5.9 & 10.4 & 21.6 & 16.0 & 1.4 \\
\hline
\end{tabular}

TABLE 9: IGSE administrators' view on overall impact of modern gadgets on IGSE management quality.

\begin{tabular}{lcccccccccc}
\hline Rating scale & 1 & 2 & 3 & 4 & 5 & 6 & 7 & 8 & 9 & 10 \\
\hline $\begin{array}{l}\text { No. of } \\
\text { answers }\end{array}$ & 3 & 17 & 39 & 52 & 229 & 154 & 288 & 473 & 261 & 262 \\
$\%$ & 0.2 & 1 & 2.2 & 2.9 & 12.9 & 8.7 & 16.2 & 26.6 & 14.7 & 14.7 \\
\hline
\end{tabular}

It should be noted that, analyzed through the prism of each oblast of Ukraine participating in the survey separately, this indicator demonstrates no significant deviations in the results, which further strengthens the representativeness of these results.

\section{Conclusions}

Considering the above, the following conclusions can be made:

(1) The scientific sources addressing the use of modern gadgets in education management are scarce and limited indicating the lack of attention of the scientific community to the new realia of today.

(2) Gadgets and messenger applications in education management have actually created a new reality that is still little understood by the educational community. This is conditioned not only by the changes in communication between the subjects and objects of education management, but also by communication within the teaching staff, with parents and other stakeholders and participants in the educational process. This means special studies are needed in order to provide theoretical, methodological, technological, and regulatory justification of these processes.

(3) Active use of gadgets and messenger applications in education management has put on the agenda the quality of such devices and their provision to subjects and objects of management by the state or local education authorities. Today, the most common practice is participants using their own devices in the process of communication, which often affects their personal interests, sometimes hampering receipt of information in full.

(4) Particular emphasis should be placed on observance of ethical rules by subjects of education management without violating their subordinates' right to privacy. Round-the-clock communication is inadmissible between subjects and objects of management unless it is an emergency. The findings presented in this study show that most of the interviewed administrators of institutions of secondary education fail to consider it when performing their professional duties.

(5) Use of gadgets and messenger applications in the professional activity also brings scientific and communicative activities to the agenda, which will enable developing and discussing particular algorithms of work in this direction, elaborating to account for ethical norms, exchanging experience, and systematizing the existing achievements and developments.

Therefore, it is expedient to conduct and focus on further studies exploring the use of gadgets to improve communication processes within and between teaching staff communities, as well as with parents and other stakeholders and participants in the educational process.

\section{Data Availability}

The answers collected within the survey for this study are available at http://www.t.ly/g9H3.

\section{Disclosure}

The polling was undertaken using the Google Form instrument in the form of a questionnaire available to the participants by link. The analysis of the results was carried out by the authors of this research themselves without any funding involved.

\section{Conflicts of Interest}

The authors declare that there are no conflicts of interest regarding the publication of this paper.

\section{Supplementary Materials}

The annex to this paper contains the questionnaire form as it was presented for the participants. (Supplementary Materials)

\section{References}

[1] S. V. Golenko, "Ispolzovaniye gadzhetov V protsesse obucheniya kak instrument upravleniya kachestvom obrazovaniya [use of gadgets in the education process as an instrument of education quality management]," Novaya Nauk Ot Idei K Rezult, vol. 90, pp. 163-165, 2016.

[2] M. A. Golovyashkina, "Pedagogycheskiy potentsial gadzhetov v obrazovatelnoi Srede Universiteta [pedagogical potential of 
gadets in the educational environment of a unversity]," Pedagog Vopr Teor I Prakt, vol. 1, no. 9, pp. 33-36, 2018.

[3] S. C. Nwali and J. O. Ugah, "School management in 21st Century using ICT: challenges and the way forward," International Journal of Scientific and Engineering, vol. 7, no. 4, pp. 67-72, 2019.

[4] D. Serhan, "School principals' attitudes towards the use of technology: United Arab Emirates technology workshop," Turkish Online Journal of Educational Technology, vol. 6, no. 2, pp. 42-46, 2007.

[5] D. R. Krishnaveni and J. Meenakumari, "Usage of ICT for information administration in higher education institutions a study," International Journal of Environmental Science and Development, vol. 1, no. 3, pp. 282-286, 2010.

[6] M. S. Njoka, The Management Challenges of Using Information Communication Technology for Administration at Secondary Schools in Kirinyaga County, UNISA, Adelaide, Australia, 2015.

[7] A. K. Kupoluyi, "Information communication technologies and universityadministration in Nigeria," International Journal of Humanities and Social Science Invention, vol. 7, no. 06 , pp. 36-42, 2018.

[8] S. Gedwar, Use of ICT for Administration and Management: Case Study, EMU, Eastern Mediterranean University, Gazimağusa, Famagusta, 2016.

[9] K. E. Hoque, Z. Ahmad Abdul Razak, and M. F. Zohora, "ICT utilization among school teachers and principals in Malaysia," International Journal of Educational Development, vol. 1, no. 4, pp. 17-34, 2012.

[10] J. Amesi and T. Yellowe, "Availability and utilization of information and communication technology gadgets in faculties of education in rivers state universities, Nigeria," International Journal of Education and Evaluation, vol. 4, no. 4, pp. 26-36, 2018.

[11] O. N. Jacob and D. Jegede, "Administration of information communication technology (ICT) in Nigerian secondary schools: challenges and the ways forward," Electronic Research Journal of Engineering, Computer and Applied Sciences, vol. 2, pp. 50-63, 2020.

[12] H. Dauda, "Role of ICT in secondary school administration: evidence from secondary schools in yola metropolis, adamawa state," Journal of African Sustainable Development, vol. 17, no. 7, pp. 97-107, 2019.

[13] M. Koko and H.-N. Ngulube, "Information and communication technology and job performance of secondary school administrators in rivers state," International Journal of Innovative Information Systems \& Technology Research, vol. 9, no. 1, pp. 1-12, 2021.

[14] E. E. Kabanova and E. A. Vetrova, "The use of modern electronic gadgets in the educational process of the university," European Journal of Contemporary Education, vol. 8, no. 3, pp. 524-533, 2019.

[15] S. N. Njathi, B. Ngaruiya, and P. Maithya, "Influence of principals' perception of computers on their use in administration of public secondary schools in kiambu county, Kenya," European Scientific Journal, ESJ, vol. 14, no. 31, pp. 178-190, 2018.

[16] W. Aurangzeb, T. Tahir, and K. Khan, "An exploration of college principals' technology leadership competency assessment," Global Social Sciences Review, vol. IV, no. II, pp. 222-230, 2019.

[17] V. V. Antonio and N. E. Lorenzo, "Ilocano administrators' adoption and use of ICT in the management of public secondary schools," Asia Pacific Journal of Multidisciplinary Research, vol. 7, no. 2, pp. 1-15, 2019.

[18] J. Villarreal, Correlation Study between School Administrators' Technology Leadership Preparation and Technology Integration, p. 121, Concordia University, Montreal, Canada, 2019.

[19] M. Spante, "Struggling with leading digitalization: diverse experiences among school and preschool principals," International Conference on Information Communication Technologies in Education, vol. 30, pp. 35-46, 2020.

[20] N. İra, A. Geçer, and İ Çolak, "Detecting the opinions of the secondary school administrators regarding the use of mobile technologies for educational purposes," Educational Policy Analysis and Strategic Research, vol. 14, no. 3, pp. 290-311, 2019.

[21] E. S. Uko, U. F. Mbon, J. E. Okon, V. O. Ebuara, and F. O. Arop, "Principals characteristics and the utilization of internet tools for school management: a survey of secondary school managers' perceptions," Journal of the Social Sciences, vol. 48, no. 3, pp. 2558-2572, 2020.

[22] N. Prykhodkina and T. Makhynia, "Using social media in school Management : experience of Ukraine and United States of America," EasyChair Preprint, vol. 9, 2020.

[23] I. Alvi and T. Alvi, "Assessing quality of higher senior secondary school management and administration services with special emphasis on the use of ICT : viewpoint of students," Amity Journal of Management Research, vol. 3, no. 2, pp. 53-63, 2018.

[24] J. M. R. Asio and S. A. Bayucca, "Spearheading education during the COVID-19 rife: administrators level of digital competence and schools readiness on distance learning," Journal of Pedagogical Sociology and Psychology, vol. 3, no. 1, pp. 19-26, 2021.

[25] N. Mythili, "Governance and leadership for achieving higher quality in school education: a study of Sikkim," Indian Journal of Public Administration, vol. 65, no. 2, pp. 298-324, 2019.

[26] State Statistics Committee of Ukraine, "Zaklady zahalnoi serednoi osvity [institutions of general secondary education]," Available from: http://www.ukrstat.gov.ua/operativ/operativ 2005/osv_rik/osv_u/znz_u.html. 